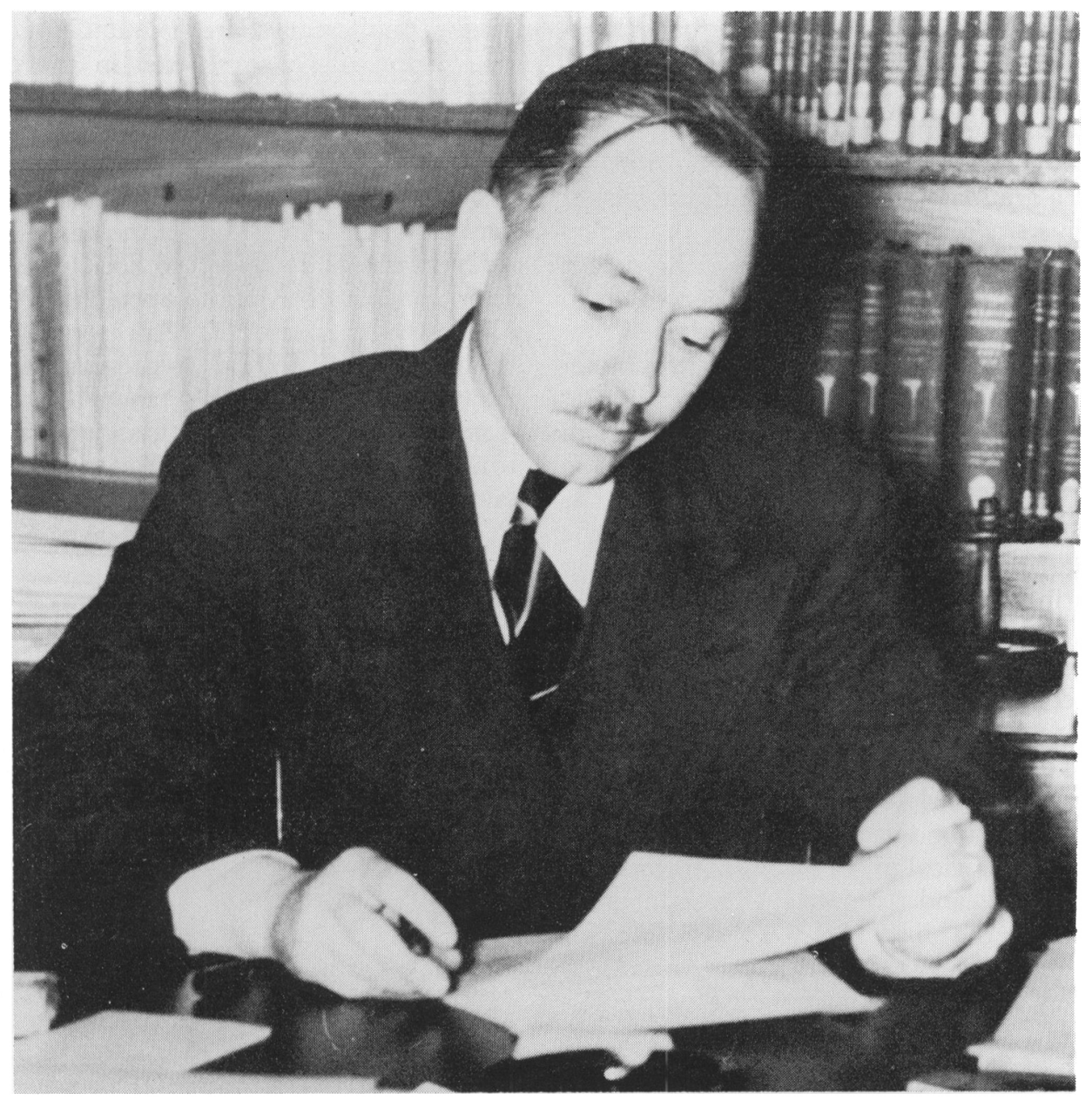

\title{
PAUL LEMEN COOPER
}

\section{9-1961}

Plains archaeology lost one of its pioneers and most dedicated scholars with the death of Paul L. Cooper at Rice Lake, Wisconsin, on April 14, 1961. Although not actively engaged in the field during the last few years his interest in the Plains area extended from the 1930's when he attended the University of Nebraska and received his M.A. degree in 1936. His thesis published in 1936, "Archaeology of Certain Sites in Cedar County, Nebraska" still stands as one of the finest examples of organized data from this area.

Paul's analytical mind and sense of scientific procedure is reflected in Plains archaeology today. He was largely responsible for many laboratory and field procedures which are now utilized. Some of these, such as the site numbering system orginated during the 1930's when he served as archaeologist for the Nebraska State Historical Society 1936-38, and as Supervisor and State Director of the WPA Archeological, Paleontological and Museum Project 1938-41. 
Paul was born in Cuba City, Wisconsin, February 11,1909 and was educated in the $W$ isconsin public schools. In 1931 he received his A.B. degree from the University of $W$ isconsin with a major in sociology and anthropology. In 1934 he became a graduate assistant in anthropology at the University of Nebraska. During the period of 1941-44 he was an assistant in anthropology at Columbia University where he completed the major work toward the Ph.D. degree.

His field research started during the summer of 1931 when he worked in the Southwest as a member of the archaeological expedition from the Field Museum of Natural History. In 1933 and 1935 he worked in Illinois. During the years of 1934 to 1941 Paul worked in the Nebraska area with the exception of 1936 when he was in the Tennessee Valley. From 1946 to 1955 he was with the Missouri Basin Project of the River Basin Surveys in Lincoln where he served as Field Director during the period of 1950 to 1952 .

It was during this period that Paul's contribution was particularly outstanding. He was able to utilize his prior experience with large scale WPA archaeological projects to set up workable administrative and laboratory procedures to fully utilize the limited funds available for salvage archaeology. Paul was also active in the survey and excavation program which followed. His surveys of the Fort Randall Reservoir area of South Dakota and the Heart Butte Reservoir area of North Dakota with the reports that followed provided a general framework of cultural sequence that has not been greatly modified by the extensive excavation program that has followed. His keen insight and ability to appraise a site on the basis of limited collections is reflected in the appraisal reports for these reservoirs.

I first met Paul in the spring of 1935 when as a high school volunteer student I was a member of the Nebraska State Historical field party working under A. T. Hill's direction. During the quarter of a century that I worked with him and knew him I found him to be a most scholarly and kindly man. He was generous with his time in helping others with their problems. He had outstanding ability as an editor which was utilized in many ways. From 194346 he was an editorial assistant for the Society for American Archaeology. He was co-editor for the publication Earthbound China by Fei and Chang. He also assisted in the editorial work on many publications by his colleagues.

In 1939 Paul married Dorothy Thurlow who shared with him much of his field work. He was a member of the Society for American Archaeology, the American Ethnological Society, the Nebraska State Historical Society, Sigma Xi, Beta Chapter of Alpha Kappa Delta Society, a Fellow of the American Anthropological Association and a Fellow of the American Association for the Advancement of Science. From 1955 to 1961 he was associated with the firm of Robert G. Cooper Associates of Rice Lake, Wisconsin.

Marvin F. KivetT

Ths list does not include book reviews or the site and survey appraisals of limited distribution written for the River Basin Surveys.

1936

Archeology of Certain Sites in Cedar County, Nebraska. Chapters in Nebraska Archaeology, Vol. 1, No. 1, pp. 5-145. Lincoln.

1937

The Schrader, Champe, and Fremont I Sites. With A. T. Hill. Nebraska History Magazine, Vol. 17, No. 4, pp. 221-92. Lincoln.

\section{8}

The Archeological Campaign of 1937. With A. T. HuL. Nebraska History Magazine, Vol. 18, No. 4, pp. 237359. Lincoln.

1940

Report of Explorations (1938). Nebraska History Magazine, Vol. 20, No. 2, pp. 94-151. Lincoln.

1946

The Institute Explores the Norton Site. Cranbrook Institute of Science News Letter, Vol. 15, No. 6, pp. 71-3. Bloomfield Hills.

1949

Recent Investigations in Fort Randall and Oahe Reservoirs, South Dakota. American Antiquity, Vol. 14, No. 4, pp. 300-10. Menasha.

An Archeological Survey of the Fort Randall Reservoir, South Dakota. Proceedings of the Fifth Plains Conference for Archeology, University of Nebraska, Laboratory of Anthropology, Note Book No. 1 . Lincoln.

1955

The Archeological and Paleontological Salvage Program in the Missouri Basin, 1950-1951. Smithsonian Miscellaneous Collections, Vol. 126, No. 2. Washington.

\section{8}

Archeological Investigations in the Heart Butte Reservoir area, North Dakota. River Basin Surveys Papers, No. 9, Bureau of American Ethnology, Bulletin 169, pp. 1-40. Washington. 